\title{
Solidaritas Sosial Pedagang Kaki Lima terhadap Tingkah Laku Konsumen di D.I Yogyakarta
}

\author{
Djaja Hendra \\ Prodi Sosiologi, Fakultas Ilmu Sosial dan Ilmu Politik, Universitas Widya Mataram \\ Djajahendraaa@gmail.com
}

\begin{abstract}
The presence of street vendors in Indonesia sometimes quiet disturbing especially for pedestrian and the motorist. However, they are also needed by the housewives to buy to rather than going to the market, supermarket or mall just to buy few things or only for a walk. Usually the street vendors had actually had place by the policy of the local government, however, maybe because of the little people know or with some other reason, the available places sometimes are left unused. The research is done towards 20 respondents with qualitative study. The method used is the phenomethologist. The result of the research gotten are as follow: First, most of the respondents come from Tegal city, approaching another big cities in Java, second, most of the local citizens search for additional income from that place; third, generally the things prepared are fast food; generally the sellers from outside of the region go with their own vehicle and using pushed carriage for the local citizen.
\end{abstract}

Keyword: seller, fast food, ride

\section{Pendahuluan}

Para pedagang kaki-lima atau sektor informal, seperti yang kita ketahui, banyak bertebaran di kota-kota besar di Indonesia. Para pedagang tersebut berjualan di tempat-tempat yang cukup strategis meski mungkin tempat berjualan dimaksud terlarang buat berjualan tanpa terkecuali termasuk provinsi D.I Yogyakarta. Tujuan utama mereka hadir dan berkerumun di kota-kota besar, tidak lain, adalah untuk meraih keuntungan sebesar-besarnya dari parakonsumen. Kadang-kadang keberadaan mereka tanpa memperhatian aspek kebersihan, keindahan, kegizian dan mungkin juga aspek kekuatan fisik bangunan (akan roboh) sehingga bisa jadi begitu kotor, kumuh dan tidak beraturan di sana-sini. Biasanya kehadiran mereka berada di tempat-tempat atau jalan-jalan strategis di suatu wilayah perkotaan dan pusatpusat keramaian. Tak jarang karena tempat dan jalan-jalan strategis demikiansering mereka tempati, yang terpenting dapat menarik keuntungan meski dapat saja telah keluar dari tempat yang diizinkan. Sehingga para pejalan kaki tak jarang harus berbagi tempat dengan mereka dan para pejalan kaki dapat saja terlempar ke jalan-raya (aspal) tempat lalu-lintas kendaraan, dan karenanya, dapat membahayakan jiwa para pejalan kaki atau orang lain itu sendiri. 
Atau, dapat saja menghambat laju jalannya kendaraan karena para pedagang tumpah-ruah di jalan raya. Seperti yang kita simak baik dengan mata-telanjang di lapangan maupun di televisitelevisi. Kehadiran mereka dapat saja mengganggu jalan dan tempat-tempat yang sudah disediakan. Tak jarang kita saksikan mereka diintimidasi, diusir dan diburu bahkan tak jarang dipukuli oleh para petugas maupun Satpol PP di suatu wilayah perkotaan dengan alasan Perda. Alasan klasik yang dikemukakanpara pedagang suatu kota, misalnya, pada umumnya bahwa, tempat-tempat atau trotoar-jalan yang disediakan pemerintah lokal adalah jarang para pembeli (sepi). Biasanya tempat-tempat yang disediakan tidak strategis, bukan jalan umum, atau tempat berjualan jauh dari tempat pemukiman dan pelosok.

Tentu, penelitian ini tidak dilakukan terhadap para pedagang dengan mobilitas tinggi sehingga mudah untuk berpindah-pindah tempat, seperti menggunakan sepeda kayuh maupun sepeda motor. Mereka umumnya pulang larut malam dan sulit untuk diwawancarai. Juga dapat mengganggu waktu istirahat mereka. Transportasi yang ada berkaitan langsung dengan dagangan mereka dan transportasi yang digunakan hanya untuk meletakkan barang dagangan belaka (gerobak, sepeda, motor). Dan menetap di tempat tersebut untuk beberapa waktu lamanya. Katakan untuk 7-8 jam lamanya. Setelah itu, kendaraannya hanya di parkir di sekitar tempat mereka berjualan. Andaikan waktu menjelang malam mereka kembali ke tempat kos masing-masing. Terpenting mudah dilihat dari pandangan mata mereka dan terjangkau. Jadi bukan portabel yang mudah dipindah-pindahkan. Termasuk bila dikejar petugas.

\section{Metode Penelitian}

Penelitian fenomenologis ini (Craib, 1984: 126) dilakukan di Kecamatan Mantrijeron; merupakan salah satu dari 13 kecamatan yang ada di Kotamadya Yogyakarta (total penduduk 417.744 orang, dengan 303.805 orang laki-laki dan perempuan ada sejumlah 213.899 orang), dengan tiga kelurahan yaitu Kelurahan Gedungkiwo; Kelurahan Suryodiningratan dan Kelurahan Mantrijeron itu sendiri. Pilihan kepada Kecamatan Mantrijeron, dengan responden di tiga kalurahan berjumlah 20 responden. Pertama, karena letaknya berbatasan dengan Kabupaten Bantul. Jika ini yang dijadikan alasan tentu saja tiga kecamatan lain akan protes seperti Kecamatan Umbulharjo, Kecamatan Mergangsan dan Kecamatan Kotagede bahkan ketiga kecamatan yang disebutkan jauh lebih luas dari Kecamatan Mantrijeron; tetapi kedua, keempat kecamatan yang disebutkan itu semuanya berbatasan langsung dengan Kabupaten Bantul; ketiga, sama-sama memiliki rumah kos tetapi Kecamatan Mantrijeron yang paling banyak bermukim para pedagang kaki-lima. Keempat, di luar wilayah lain di kotamadya bagian utara atau timur yang juga memiliki kampus dan sekolah- 
sekolah maka bagian selatan adalah tempat bermukim kampus-kampus dan sekolah-sekolah di luar Kabupaten Sleman bagian utara. (Kota Yogyakarta dalam Angka, 2017). Pilihan-pilihan kecamatan (untuk kelurahan) menggunakan stratified random sampling. Pilihan kepada Kecamatan Mantrijeron dengan tiga kelurahan dilakukan dengan purposive. Sementara untuk ketiga kelurahan yang ada di respondennya dilakukan dengan cara random karena sejak awal sudah ditentukan terlebih dahulu respondennya yaitu para pedagang kaki-lima.

Para pedagang kaki-lima karena kerap kali diusir dan diburu oleh petugas maupun Satpol PP maka tak jarang mereka main kucingkucingan seperti tidak bejualan untuk sementara waktu, atau berjualan di tempat lain dan lain sebagainya; yang penting, keuntungan maksimal. Terlepas dari itu semua, mereka berjualan di trotoar atau tempat-tempat cukup strategis lainnya; dari sisi para pedagang yang pentingsemakin banyak pembeli meski mungkin di daerah itu tidak diizinkan/dilarang oleh pihak keamanan dan kebijakan-kebijakan pemerintah kota misalnya. Penelitian menggunakan pendekatan fenomenologis dan dilakukan di pertigaan jalan. Satu jalan tepat berada di pertigaan jalan, sementara lainnya berada di jalan lurus terus pada tempat yang sama. Para pedagang dengan mobililitas rendah terbukti bahwa tidak satu pun dari mereka yang berdagang dengan tidak permanen. Sehingga semakin banyak para pedagang berjualan ditempat tersebut dan semakin tidak terkontrol hingga ke pojok-pojok jalan dan halaman rumah-rumah penduduk (kebetulan rumah mereka berada di sisi jalan) diisi oleh para pedagang sepenuhnya. Para pedagang memang jarang yang menjual barang dagangan seperti baju maupun celana, alat-alat rumah tangga dan lain-lain kecuali makanan kecil (kuliner) belaka. Pertanyaan yang layak dikemukakan adalah, apakah tidak terjadi persaingan di antara para pedagang kaki lima dalam memperoleh keuntungan yang maksimal dari para konsumennya? Terlihat memang tidak kelihatan dipermukaan bentuk-bentuk persaingan tersebut, tetapi di balik itu, tentu ada saja yang biasa-biasa saja atau menggunakan hal-hal di luar rasio manusia seperti ke dukun, orang pintar, paranormal atau hal-hal lain.

\section{Hasil dan Pembahasan}

\section{A. Kategori Solidaritas Sosial}

Istilah solidaritas sosial untuk pertamakali sebagai sebuah konsep mungkin sudah pernah dimunculkan para ahli. Tetapi istilah ini, yang paling khusus, dikemukakan oleh seorang sarjana Perancis Emile Durkheim (Johnson, 1994: 167) yang menyebut solidarias sosial diartikan sebagai petunjuk kepada suatu keadaan hubungan antara individu dan/atau kelompok yang didasarkan pada perasaan moral dan kepercayaan yang dianut bersama yang diperkuat oleh pengalaman emosional bersama. Ikatan ini lebih mendasar dari pada hubungan kontraktual yang dibuat atas persetujuan rasional, karena hubungan-hubungan serupa itu 
mengandaikan sekurang-kurangnya satu tingkat/derajat konsensus terhadap prinsipprinsip moral yang menjadi dasar kontrak ini.Bahkan menurut Durkheim solidaritas sosial itu masih bisa dibagi lagi menjadi solidaritas mekanikdan solidaritas organik. Solidaritas mekanik diartikannya sebagai kepercayaan bersama, cita-cita dan komitmen moral; dan solidaritas organik diartikan sebagai saling berhubungan dan saling tergantung.Dalam hubunganini, tentu kita tidak lebih jauh meneliti solidaritas mekanik maupun solidaritas organik tetapi cukup dengan solidaritas atau solidaritas sosialbegitu saja yang diartikansebagai nilainilai dan norma-norma hidup dalam masyarakat yang bersangkutan (dalam hal ini para pedagang). Nilai-nilai dan norma-norma ini yang menjadi pedoman/panduan dan orientasi dalam kehidupan para pedagang secara keseluruhan. Inilah yang menyebabkan solidaritas sosial yang terbentuk di dalam diri para pedagang kaki lima itu. Adanya rasa kebersamaan (satu penderitaan)di antara para pedagang untuk memperoleh keuntungan bersama(sesuai dengan jenis dagangannya) dari parakonsumen. Berbicara tentang keuntungan-keuntungan yang diperolehitu biasanya berangkat dari keuletan, ketabahan dan keikhlasan dari mereka sendiri serta percaya kepada Tuhan Yang Maha Esa; artinya,semua telah dilakukan oleh para pedagang sendiri,akan tetapi Tuhanlah yang mengatur dan menentukan segala-galanya.

Berdasarkan gambaran ini, tentu pada kenyataan yang ada melaluipara pedagang, ada yang benar - benar ramai pembeli atau ada pula yang jarang atau bahkan sepi pembeli; padahal semua kuliner yang dijajakan atau dijual kebanyakan ada yang sama dan bahan makanan baik makanan seperti makanan kecil maupun makanan dalam bentuk sayur-mayur, lauk-pauk serta minuman dari panas atau dingin juga disediakan. Soal rezeki sudah ada yang mengatur, demikian kata sebagian besar di antara para pedagang. Sehingga persainganpersaingan di antara mereka kelihatannya tidak terlalu nampak kecuali ada yang kasak-kusuk (sekaligus sumber fitnah). Memang diakui bahwa ada satu dua orang yang menyimpang dari ketentuan, mengingat jualannya mungkin terlihat tidak higienis, kotor, berbau, menggunakan bahan pengawet, tempat/lokasi dipojok jalan, tidak menarik jika ada pembeli datang; akibatnya mereka menggunakan dukun, orang pintar, paranormal dan lain sebagainya. Padahal jika semua dilakukan dengan sungguhsungguh dan cara-cara yang bersih, tekun, santun dan higienis serta promosi dalam bentuk wanita cantik-ayu atau reklame kertas yang ditempelkan ditempat-tempat strategis maupun omongan orang dari satu orang ke orang lainnya; tentu hasilnya akan sangat berbeda. Tetapi seperti biasa dilakukan di pusat-pusat kota atau di perbatasan kota/keramaian cukup baik jika dilihat oleh mata telanjang dan lain sebagainya;padahal promosi demikian sangat jarang diketahui dan dilakukan para pedagang. Sesungguhnya para pedagang tidak sempat untuk melakukan hal-hal yang demikian 
terutama berangkat dari etnis tertentu (secara random dalam penelitian ini terbukti bahwa yang melakukan tindakan tercela itu kebanyakan penduduk sekitar). Mungkin ketidak-sempatan itu lebih dikarenakan mereka tidak cukup waktu atau tempat-tempat di mana lokasi tersebut berada. Oleh karenanya jika ada yang menuduh tanpa bukti lebih mudah dilakukan daripada mengumpulkan barang bukti baru yang mungkin bersifat ilmiah dan masuk akal. Waktu memang menjadi krusial. Tetapi dengan alokasi waktu pulalah patut dipertanyakan, kenapa mereka sampai pergi ke dukun, paranormal maupun orang pintar dan lain sebagainya; yang mungkin tempatnya di pelosok desa bahkan di luar kota sekali pun, bukankah cara-cara tersebut membutuhkan waktu pula?

Padahal jika para pedagangkaki-lima itu untuk mendapatkan keuntungan yang lebih besar, tentu harus membuat dan mengolah sendiri dagangannya daripada hanya sekadar menjajakan dagangan milik orang lain. Kebersihan dan higienitas dalam menjajakan barang dagangan harus terjaga dengan baik serta di tempat-tempat yang enak dipandang sehingga membuat parakonsumen dapat tertarik.Semula mungkin hanya untuk melihat-lihat dan jalanjalan serta tidak bermaksud untuk membeli, walau pada akhirnya mereka membeli juga. Itu merupakan suatu bentuk strategi. Tentu saja konsumen jenis ini juga ada di mana-mana dan di mana pun mereka berada. Jadi memang tidak mudah untuk menjaring konsumen demikian terlebih dagangan yang dibawa terbatas kecuali jika penduduk sekitar ingin ikut berdagang (walau akhirnya mereka pun ikut berdagang). Walau harus diakui tingkat solidaritas yang dibangun (sama-sama sebagai penjual) menjadi terbelah, yang satu adalah para pedagang umum dan satunya lagi adalah para pedagang penduduk sekitar. Kesan kuat tersebut makin nyata-terlihat jika mau melakukan sesuatu tindakan maka penduduk sekitar jauh lebih menangan ketimbang para pedagangyang seolah-olah tidak memiliki tempat berjualan. Padahal kalau kita cermati, kedua-duanya tidak boleh saling menyerang satu terhadap yang lain hanya untuk memperebutkan sesuatu yang dipersengketakan.

Nilai-nilai dan norma-norma memang dalam batasan tertentu dapat terlihat di antara para pedagang termasuk para pedagang penduduk sekitar yang ikut pula berjualan. Tetapi kekuatan-kekuatan itu jauh lebih permanen di antara para pedagang penduduk sekitar terutama terhadap tindakan-tindakan sesuatu yang berjauhan/tidak ada hubungan dengan dagangannya, misalnya, perebutan lapak, pakaian yang dikenakan oleh mereka dan lain sebagainya; acapkali jadi persoalan tetapi yang berkaitan dengan makanan-jadi (siap untuk dikonsumsi) tidaklah sekuat para pedagang dari luar. Selain, sudah lama berdagang juga karena bukan orang setempat maka mereka bersungguhsungguh dalam berdagang. Sangat jarang mereka berkomunikasi dengan penduduk sekitar apalagi dengan orang lain yang hanya sekadar lewat. Walaupun para pedagang sebagian besar bukan berasal dari kota yang sama tetapi dagangan 
mereka umumnya sama dan hubungan-hubungan mereka pun dilandasi oleh rasa keprihatian (anak-istri, dapat saja tidak makan jika mereka tidak bersungguh-sungguh) yang mendalam. Mereka kadang-kadang meminjam uang antar sesama andaikan satu pihak merasa kekurangan, bahkan sampai meminjam pakaian jika ada yang tidak punya (pakaian yang itu-itu saja yang dikenakan) adalah bukti nyata dari kekuatankekuatan solidaritas antar mereka. Atau saling berganti makanan yang dijajakan manakala di tempat mereka sudah habis terjual atau masih tinggal sedikit, jika ada konsumennya mau membeli banyak (mengenai keuntungan cukup dengan hanya tinggal mengambil beaya pokoknya saja tanpa uang lelah). Sesama pedagang mereka tidak mengambil keuntungan. Tetapi kalau yang terjadi sebaliknya, mereka akan dimusuhi dan dikucilkan dengan sesama pedagang. Jadi kalau makanan (kuliner) yang dijual para pedagang jauh lebih kuat, ulet dan penuh kesabaran dibandingkan dengan para pedagangpenduduk sekitar. Contoh, pernah ada suatu kejadian di mana parapenduduk sekitar berseteru dengan para pedagang (umumnya mereka berasal dari Tegal), tidak perduli siapa yang benar atau salah tetapi orang-orang yang berseteru dan melibatkan orang lain/sekitar maka orang yang terlibat dalam perseteruan tadi dan (para pedagang) maka sudah dipastikan orang tersebut tidak kelihatan lagi di pertigaan jalan itu di hari-hari berikutnya. Mereka pindah ke lain tempat dan mungkin juga ke kota lain untuk selama-lamanya.
Contoh semacam ini bukan barang baru. Terpenting nilai-nilai dan norma-norma sosial, sebagaimana dikatakan Durkheim, begitu kuat mengikat di kalangan parapedagang. Jika mereka pindah maka akan membentuk rasa bersama di tempat yang baru. Bahkan mereka dapat saling-kunjung ke rumah masing-masing meskipun letak rumah mereka berjauhan (kota yang berbeda). Mereka mengikat diri dalam suatu persahabatan yang erat atau jika jenis kelamin yang berbeda dapat saja mengikat diri dalam ikatan perkawinan. Padahal mereka mungkin terikat dengan perkawinan sebelumnya. Baik pihak perempuan maupun pihak laki-laki (adminitrasi KUA biasanya kurang baik). Ini yang lebih konyol yaitu dapat merenggangkan hubungan suami-istri ditempat asal. Tak jarang suami-istri itu pisah ranjang atau bentuk-bentuk lain yang lebih fatal yaitu perceraian. Sangat banyak kita temukan mereka yang beristri lebih dari satu, dua atau kawin siri dan lain sebagainya. Tetapi tidak demikian dengan penduduk sekitar. Walau tidak terlalu kelihatan tingkat persaingan di antara mereka tetapi cukup tinggi pula tingkat persaingan dan menegangkan itu. Terbukti, dengan munculnya banyak isu-isu/rumor yang tidak jelas sumbernya di antara penduduk yang berdagang maka di tempat tinggal/perkampungan mereka muncul rumor serupa. Tetapi bisa pula diduga bersumber dari para pedagang atau orang lain yang berada di perkampunganitu sendiri, sehingga perkampungan tersebut menjadi ramai kasak-kusuk bahkan mereka seolah-olah tidak 
saling bertegur-sapa maupun tidak saling mengenal satu sama lain. Untuk berbagai perkampungan dapat saja datang dari keluarga yang pas-pasan atau yang miskin sama sekali.

\section{B. Tempat atau Jalan Strategis}

Mungkin persoalan tempat atau jalan yang digunakan untuk menjajakan barang makanan oleh para pedagang dari setiap penjual tentu saja mencari tempat yang cukup strategis untuk menghadang pembeli berkendaraan maupun hanya sekadar melihat-lihat saja sudah dilakukan (konsumen). Tempatnya pun lebih bersifat alamiah daripada ilmiah. Alamiah dimaksud dengan sistem trial and error. Bermula dari tempat beristirahat setiap pedagang yang menggunakan sepeda, barang satu-dua jam hanya untuk mengaso (beristirahat) lantas kemudian melanjutkan perjalanan kembali danmeneruskan berdagang hingga menjelang Isya; lama kelamaan mereka menjadi menetapkan/menitipkan barang satu-dua orang dari siang hingga larut malam. Secara bersamaan di tempat berjualan belakangan dilengkapi pula dengan ATM dari Bank BNI dan Bank Mandiri, sehingga suasana semakin terang-benderangpada malam hari layaknya tempat-tempat hiburan malam. Jangan kaget jika kita melihat perkembangan ini, kalau para pedagang pulang ke rumah hingga larut malam bahkan menjelang pagi terutamajika esok harinya hari libur (hari Sabtu dan hari Minggu serta hari-hari libur/tanggal-tanggal merah). Mungkin sudah banyak yang pulangke rumah jika penjualnya tidak khusus seperti penjual buku-bekas, gerobak asinan, gerobak buah-buahan yang dipotong kecil-kecil tetapi bagi yang menjual kuliner dan makanan kecil lainnya tentu menunggu hingga dagangannya laku/habis terjual. Hadirnya para pedagang membuat penduduk sekitar sudah tidak takut dan khawatir lagi jika hendak keluar malam, misalnya untuk membeli sesuatu keperluan. Bahkan toko-toko yang dikelola penduduk (usahanya bertoko) letaknya 100 meteran atau lebih, sekarang banyak dikunjungi oleh parakonsumen terutama anak-anak SD sampai SMA hanya untuk melengkapi keperluan sekolah mereka tanpa perlu menunggu esok hari, padahal sebelumnya kita tidak tahu kapan buka toko dimaksud,atau sama sekali tidak buka/tutup. Dalam banyak kasus sangat tergantung dari kesediaan SPG (Sales Promotion Girl) yang didatangkan dari penduduk sekitar atau saudara dari parapedang itu sendiri. Dari hasil wawancara terhadap para pedagang, adalah juga, untuk mendapatkan hasil yang maksimal, selain keeratan hubungan antarsaudara atau famili-dekat karena mereka memang jarang bertemu keluarga kecuali masa lebaran atau dadakan seperti ada keluarga yang meninggal atau arisan bersama sebulan sekali. Demikian kalau mereka yang memiliki toko di pingiran jalan.

Selanjutnya, pilihan kepada trotoar-jalan oleh para pedagang memang digunakan untuk menjaring para konsumen yang berada di jalanraya. Tentu tidak seperti jalan-raya pada umumnya tetapi lokasi-jalan adalah di 
pengkolan-jalan yang mungkin tidak umum dilakukan. Bagi petugas atau satpol P.P sepanjang tidak mengganggu lalu-lintas jalan orang mungkin tidak terlalu ada persoalan; di samping, barang-barang yang dijajakan dijaga kebersihan dan hiegienitasnya. Sebetulnya jalandi pengkolan itu bukanlah jalan raya/umum seperti yang kita ketahui ada trotoar jalan di kiri maupun kanan jalan yang bentuknya sangat tinggi bagi kendaraan bermotor untuk dilewati. Sebagaimana dikatakan di atas bahwa trotoar dimaksud hanya rendah saja dan setiap kendaraan bermotor atau tidak saja dapat dilewati bahkan pada lokasi-lokasi tertentu hanya terdiri dari konblock (bukan aspal) yang diatur agar kelihatan rapi dan enak dipandangmata. Juga, seperti dikatakan tadi, awalnya adalah tempat para pedagang keliling untuk beristirahat/mengaso dan saling bertukar-pikiran di antara mereka. Berjualan pun hanya sekadar menjajakan begitu saja tanpa merespons terlalu dalam setiap persoalan di mana penduduk sekitar ini ada yang ikut-ikutan berjualan bersama-sama para pedagang. Tujuannya, tidak lain, adalah untuk menghadang parakonsumen yang sedang melewati jalan itu baik penduduk sekitar maupun orang lain yang biasa lewat agar mau mampir barang sesaat sambil melepas lelah. Jika mereka memiliki waktu luang yang banyak. Di rumah pun kebanyakan hanya perumnas bukan rumah pribadi dengan halaman yang luas.

Sebenarnya, trotoar-jalan sebagaimana dikatakan tadi, tidaklah terlalu tinggi mirip trotoar-jalan pada umumnya. Lebih mirip halaman rumah/kantor karena letaknya di pengkolan-jalan. Mirip halaman perkantoran memang demikian adanya.Jadi halaman perkantoran yang dibuatkan jalan untuk umum. Siapa pun dapat berjalan di sana, bagi yang mengetahui. Tentu yang di dekat perkampungan maupun orang lain/umum yang telah biasa berjalan di sekitar itu. Kalau mengikuti sejarahnya, kenapa jalan yang ber-konblok (umumnya tidak digunakan untuk jalan-raya) memang dahulunya adalah jalan umum milik perkampungan.Jalan tersebut agaknya dapat menembus ke jalan ring-road di D.I Yogyakarta. Dahulu adalah jalan-tembus yang dilakukan penduduk untuk berkomunikasi dan bertransaksi serta bersosialisasi. Tetapi karena jalan tersebut berikut berupa jalan-tanah berbatu (sekarang sudah di aspal) dan sudah dibeli pihak perkantoran maka jalan-tanah berbatu milik perkampungan, oleh perkantoran itu tetap dibuatkan jalan yang sama, hanya halamannya saja di-konblok mengikuti kebijakan perkantoran demikian, wajar jika kemudian tidak tinggi layaknya trotoar jalan-raya pada umumnya. Mungkin kondisi yang ada lebih rendah lagi. Itulah sebabnya kenapa trotoar tersebut tidak terlalu tinggi tetapi menyesuaikan dengan ketinggian perkantoran yang telah ada atau menyesuaikan dengan jalan perkampungan dahulu tanpa melakukan perubahan sama sekali. Nampaknya, meskipun perkantoranctersebut dapat saja menyesuaikan dengan trotoar-jalanraya, karena masa itu, kekuasaan Orde Baru masih begitu kuat maka dapat saja dilakukan 
seperti jalan-raya pada umumnya. Tetapi tidak demikian. Sehingga dalam bentuk yang rendah saja. Dengan bentuk yang seperti itu mendorong setiap orang untuk memanfaatkannya termasuk kendaraan bermotor maupun mereka yang berjualan. Padahal digunakan untuk pejalan kakipada umumnya tetapi tidak tertutup kemungkinan kendaraan bermotor pun di trotoar pula. Di sinilah para pedagang itu menjajakan barang dagangannya dan berkumpul. Hadanganhadangan terhadap parakonsumen yang sedang lewat atau penduduk sekitar dilakukan di tempat seperti itu. Jika dihari biasa (di luar ramadan) penjualnya tidaklah sebanyak dan seramai ini. Untuk penduduk sekitar yang ingin mengambil keuntungan besar tentu makanan yang dijajakan yakni dibuat sendiri meski mungkin kadangkadang tidak merata/tidak sama antar makanannya tidak seperti para pedagang pada umumnya.

Selanjutnya, bagi penduduk sekitar yang berjiwa pedagang (para pedagang) karena tempat yang seolah-olah milik sendiri, mereka dapat bolak-balik ke rumahnya (perkampungan) untuk berbagai keperluan tetapi yang paling banyak dilakukan adalah yang ada kaitan dengan dagangan mereka mulai dari penambahan jumlah makanan (dagangannya laris), menggantikan kulit/kertas makanan yang rusak atau buruk, ditukar dengan makanan yang diduga lebih laris dari yang selama ini mereka jajakan dan lain sebagainya. Biasanya rumah yang dimiliki para pedagang untuk semua pedagang baik para pedagang perkampungan sekitar sendiri maupun para pedagang dari luarkota kurang terurus, tidak ada yang membersihkan halaman rumah maupun perabotan rumah-tangga karena orang yang tinggal di rumah tidak ada. Kecuali ada remaja putri atau orangtua dari para pedagang. Termasuk kegiatan kampung sangat tergantung dari jenis kegiatannya. Tetapi jika ada orang yang meninggal/kematian di perkampungan sekitar apalagi ada hubungan saudara dengan penduduk atau para pedagang tentu mereka dapat meninggalkan dagangnya dan saudara atau anak-anak yang menunggu dagangannya, tentu parapedangang luar-kota, betapa pun jauh jaraknya, tetap pulang kampung hanya untuk beberapa waktu lamanya dan kemudian mereka berdagang-kembali setelah suasana sudah kondusif dan baik-baik saja.

Dalam penelitian pula ditemukan uruturutannya sebagai berikut. Kebetulan yang paling banyak mereka yang datang dari kota Tegal, umumnya mereka berdagang kuliner. Sedikit sekali yang berdagang di luar dagangan itu. Menyusul kota-kota besar lainnya seperti Brebes, Pekalongan, Sukoharja, Salatiga. Tetapi khusus D.I Yogyakarta ini adalah kota-kota di sekitar Yogyakarta saja seperti Klaten dan kotakota kecil yakni Delanggu, Kartosuro maupun Magelang, Muntilan dan Temanggung.

Selanjutnya, untuk parakonsumen yang dihadang oleh para pedagang mulai dari mereka yang sekadar hanya melihat-lihat atau membeli dari dagang para pedagang ada pula yang pulang kantor ikut membeli barang dagangan guna 
melengkapi meja-makan mereka. Dengan letak trotoar-jalan mirip jalan-biasa (tanpa trotoar) memudahkan mereka mampir terlebih jika mereka naik kendaraan bermotor dengan tidak meninggalkan motornya dapat langsung saling tawar-menawar dengan penjual kecuali mereka yang berkendaraan roda empat selain diparkir di tempat tersendiri sehingga mereka harus berjalan kaki ke tempat/lokasi penjual juga jika mereka akan mengambil kendaraannya parkir harus dengan membayar (biaya parkir). Tidak demikian, dengan parakonsumen yang berjalan kaki atau sepeda membeli barang dagangan tentu tidak ada biaya sama sekali. Sehingga jauh lebih hemat-irit dengan berjalan kaki dan naik sepeda,atau sepeda motor daripada kendaraan roda-empat. Disamping, tentu saja dengan berjalan kaki dan naik sepeda bentuk trotoar jalan yang tidak terlalu tinggi maka dapat dengan mudah dilewati daripada kendaraan sepeda motor atau roda-empat.

\section{Kesimpulan}

Dari hasil penelitian ini, dapat disimpulkan: pertama, pedagang-kaki lima di daerah kotamadya paling banyak berada di Kecamatan Mantrijeron tidak terlalu muncul dalam penelitian ini); kedua, usia para pedagang antara 25 sampai 45 tahun; ketiga, biasanya mereka menyediakan makanan siap-saji; keempat, jika dibandingkan dengan kecamatan lain di bagian selatan kotamadya maka Kecamatan Mantrijeron yang paling memungkinkan untuk berdagang kuliner itu; kelima, kebanyakan parapedangang ini berasal dari Tegal menyusul kota-kota besar di Jawa; keenam, letaknya yang berbatasan dengan Kabupaten Bantul dan memiliki banyak kampus maupun sekolah memungkinkan untuk dipilih.Para pedagangdalam berjualan selalu membutuhkan konsumen di mana pun mereka berada. Dalam memenuhi kebutuhan tersebut tidak jarang para pedagang melanggar aturanaturan yang telah ditetapkan (baik pusat maupun pemda) terpenting dagangan mereka dapat laku keras. Dalam kondisi ini semakin penuh dan semrawut serta tidak enak dipandang mata tetapi hal itu tetap dilakukan juga.bahkan penduduk sekitar yang memiliki watak usahawan/bisnis ikut-ikutan berjualan bersama dengan para pedagang. Mereka pun secara bersama-sama menghadang konsumen baik roda dua-empat maupun pejalan kaki di pertigaan jalan. Dengan cara demikian penduduk sekitar, yang semula kurang berani keluar malam, karena sudah seperti pasar malam; menyebabkan mereka tidak lagi merisaukan hal itu terutama dalam memenuhi kebutuhan sekolah bagi anak-anak, yang belum tentu akan buka di pagi hari. Upaya hadangan konsumen konsumen itu dalam rangka menjual habis dagangannya.

Mereka para pedagang usai menjajakan barang dagangannya kembali ke rumah/kosnya masing-masing yang cukup berjauhan satu sama lain, bahkan di lokasi yang sangat strategis itu, tempat mereka lebih jauh lagi. Tetapi di bulan suci Ramadhan kuliner makanan kecil harus mereka jual daripada yang lainnya. Untuk itu 
sering mereka bersama para pedagang penduduk sekitar harus habis terjual/laku jika tidak ingin dagangan mereka menjadi basi/busuk; dan jika dijual-kembali keesokan harinya atau mereka buang begitu saja daripada merusak makanan lain. Begitulah trik-trik yang dilakukanpara pedagang dalam menjualkan dagangan mereka. Oleh karena itu mereka ngototuntuk berjualan meskipun dapat melanggar aturan-aturan daerah setempat. Cuma di bulan ramadan saja, menurut mereka memang demikian adanya yakni jauh lebih ramai dari hari biasa. Disamping itu kalau para pedagang yang datang dari luar daerah berbeda dengan penduduk sekitar tetapi mempunyai jiwa berdagang. Nilai-nilai dan norma-norma sangat berbeda satu sama lain. Artinya, para pedagang luar kota jauh lebih erat hubungan di antara mereka daripada hubungan antarpara pedagang dari penduduk sekitar. Tidak terlalu kuat dan bisa saja persaingan dalam berdagang tercipta yang kemudian dapat terbawa ke perkampungan mereka. Terbukti dari isu-isu yang dimunculkan diantara mereka bahwa berubah menjadi fitnah.

\section{Daftar Pustaka}

Anonymous, 2017.Kota Yogyakarta Dalam

Angka. 2017. CV. Lunar Mdia. Yogyakarta

Craib, Ian, 1984. Teori-teori Sosial Modern. Rajawali Pers. Jakarta

Johnson, Doyle, Paul. 1994.Teori Sosiologi Klasik Dan Modern. Jilid I. PT. Gramedia. Jakarta. 